\title{
STRATEGI DAKWAH JAMAAH TABLIG DALAM REALITAS KONFLIK SOSIAL DI KECAMATAN MASAMBA KABUPATEN LUWU UTARA
}

\author{
Abdin Subu \\ Arifuddin \\ Usman Jasad
}

\begin{abstract}
Abstrak: Tulisan ini akan mengelaborasi tentang strategi dakwah Jamaah Tablig dalam mengatasi konflik sosial di Kecamatan Masamba Kabupaten Luwu Utara. Penelitian ini adalah penelitian lapangan (fild reseach) yang bersifat deskriptif kualitatif. Pendekatan yang digunakan dalam penelitian ini adalah pendekatan sosiologis, pendekatan komunikasi, dan pendekatan historis, serta teori-teori yang relevan dengan kajian konflik sosial dan gerakan dakwah Jamaah Tablig. Jenis data yang digunakan dalam penelitian ini yaitu data primer yang diperoleh dari informan baik itu melalui wawancara atau peneliti sendiri yang melakukan observasi. Sedangkan data sekunder merupakan data yang tidak langsung diambil dari para informan akan tetapi memalui dokumen. Metode pengumpulan data kualitatif dapat dilakukan dengan observasi (pengamatan), interview (wawancara), dokumentasi. Dalam upaya memperoleh data yang empiris mengenai masalah yang diamati dalam penelitian ini digunakan seperangkat instrumen dalam bentuk pedoman wawancara (interview guide), alat rekam peristiwa seperti tape recorder dan kamera, serta catat an lapangan (field note) untuk menghimpun informasi mengenai strategi dakwah Jamaah Tablig dalam mengatasi konflik sosial di Kecamatan Masamba Kabupaten Luwu Utara. Data diolah dan dianalisis dengan reduksi data, penyajian data, dan penarikan kesimpulan dengn uji keabsahan data melalui triangulasi.

Hasil penelitian menunjukkan bahwa strategi dakwah yang dilakukan oleh Jamaah Tablig dalam mengatasi konflik sosial di Kecamatan Masamba adalah dengan cara; a) Jaulah, yakni silaturahmi mengunjungi para pelaku konflik untuk mengingatkan agar sama-sama taat kepada Allah; b) Bayan, yakni memberikan penerangan atau ceramah agama; c) Tasykil, yakni mengajak para pelaku konflik dengan memberikan semangat untuk meluangkan waktu di jalan Allah; dan d) Bersinergi dengan pemerintah yang menghasilkan resolusi konflik yakni khuruj berbasis pesantren atau pelaku konflik di pesantrenkan.
\end{abstract}

\section{Keywords: Strategi Dakwah, Jamaah Tabligh, Konflik Sosial}

\section{PENDAHULUAN}

Islam yang bersumber pada al-Qur'an dan Hadis, adalah agama dakwah. ${ }^{1}$ Agama dakwah yang dimaksud kata Max Muller, agama yang di dalamnya terdapat usaha menyebarluaskan kebenaran dan mengajak orang-orang yang belum mempercayainya dianggap sebagai tugas suci oleh pendirinya atau oleh para penggantinya. Semangat memperjuangkan kebenaran itulah yang tak kujung padam dari jiwa para penganutnya sehingga kebenaran itu terwujud dalam fikiran, kata-kata, dan perbuatan, semangat yang

${ }^{1}$ Thomas Walker Arnold, The Preaching of Islam; A History of the Propagation of the Muslim Faith, terj. A. Nawawi Rambe, Sejarah Dakwah Islam (Jakarta: Wijaya, 1985), h. 1. 
membuat mereka sangat tidak puas sampai berhasil menanamkan nilai kebenran itu ke dalam jiwa setiap orang, sehingga apa yang di yakini sebagai kebenaran di terima oleh seluruh manusia. Perkembangan Islam pada masa Nabi Muhammad saw. melalui berbagai macam cobaan dan tantangan yang dihadapi untuk menyebarkannya. Islam berkembang dengan pesat hampir di semua lapisan masyarakat dipegang dan dikendalikan oleh Islam.

Islam juga dipahami sebagai agama risalah, yang oleh pembawanya (Nabi Muhammad saw.) harus disampaikan kepada umat sampai akhir hayatnya. Setelah itu wajib diteruskan dan didakwahkan oleh para sahabatnya, kemudian oleh pengikutpengikutnya sampai masa sekarang. Dorongan untuk meneruskan dakwah Islam adalah karena kaum muslimin meyakini bahwa penyampaian dakwah merupakan kewajiban bagi umat Islam, baik secara pribadi maupun kelompok. ${ }^{2}$

Dakwah merupakan satu bagian yang pasti ada dalam kehidupan umat beragama, termasuk agama Islam. Islam adalah agama dakwah yang bersumber dari al-Qurán yang dibawa oleh Nabi Muhammad saw. untuk mengeluarkan manusia dari kegelapan menuju cahaya keimanan yang terang benderang, memberikan pedoman dan petunjuk menuju kejalan yang lurus dan benar.

Faktor penting yang sangat menentukan berhasil tidaknya sosialisasi ajaran Islam di tengah masyarakat adalah strategi dakwah. Menurut Didin Hafidhuddin, ${ }^{3}$ prinsip dan strategi dakwah secara umum adalah; memperjelas sasaran dakwah, merumuskan masalah pokok umat Islam, merumuskan materi dakwah, menyusun paket-paket dakwah, dan evaluasi kegiatan dakwah.

Dakwah merupakan proses penyampaian nilai Islam yang menghendaki terjadinya perubahan pada diri individu, kelompok atau masyarakat yang menjadi sasaran dakwah. Hal ini berdasar pada defenisi dakwah sebagai suatu usaha memindahkan umat dari satu situasi ke situasi yang lain, yakni dari situasi negatif ke situasi positif, dari kekufuran menjadi beriman untuk mencapai keridhaan Allah swt. ${ }^{4}$

Harapan dan tujuan dakwah untuk mempengaruhi orang lain agar berubah kearah yang positif merupakan suatu hal yang sangat mulia, namun pelaksanaan dakwah tidak semudah membalik telapak tangan. Karena itu dakwah tidak bisa dilakukan secara insidentil dan asal-asalan, melainkan harus dilakukan secara sistematis dan komprehensif. ${ }^{5}$ Disamping itu, dakwah harus dilakukan dengan persiapan dan perencanaan yang matang sebelum melakukan aktifitas dakwah.

Terjadinya perubahan dalam masyarakat sebagai suatu tujuan dakwah mengisraratkan pentingnya suatu strategi yakni strategi dakwah. Karena strategi dakwah merupakan suatu perencanaan yang berisi rangkain kegiatan yang didesain unt uk mencapai tujuan dakwah tersebut. ${ }^{6}$ Di samping itu, strategi dakwah juga dipahami sebagai upaya-upaya (cara) untuk mencapai tujuan dakwah. ${ }^{7}$

${ }^{2}$ M. Quraish Shihab, Membumikan al-Qurán (Cet. XXII; Bandung: Mizan, 2001), h. 194.

${ }^{3}$ Didin Hafidhuddin, Dakwah Aktual (Cet. I; Jakarta: Gema Insani Prees, 1998), h. 71.

${ }^{4}$ Anwar Arifin, Dakwah Kontemporer; Sebuah Studi Komunikasi (Cet. I; Yogyakarta: Graha Ilmu, 2011), h. 4.

${ }^{5}$ Faizah dan Lulu Muchsin Efendi, Psikologi Dakwah (Cet. II; Jakarta: Kencana, 2009), h. 88-89.

${ }^{6}$ Moh. Ali Aziz, Ilmu Dakwah, Edisi Revisi, h. 349.

${ }^{7}$ Malik Idris, Strategi Dakwah Kontemporer(Cet. I; Makassar: Sarwah Press, 2007), h. 7. 
Salah satu komunitas muslim yang aktif dalam bidang dakwah adalah Jamaah Tablig. Jamaah Tablig merupakan gerakan non formal yang bergerak secara berkelompok, khususnya dalam bidang dakwah Islam. Jamaah Tablig dalam menyampaikan ajaran Islam, berupaya menampilkan sikap yang menurut mereka dilakukan oleh Rasulullah saw. dan sahabatnya. Dakwah dalam pandangan Jamaah Tablig merupakan suatu hal yang sangat mendasar, sebab inti dari kegiatan dakwah ialah menyebarluaskan ajaran agama, sementara agama dalam kehidupan umat manusia menempati posisi strategis, bahkan yang lebih penting lagi ialah bagaimana mewujudkan agama dalam diri setiap manusia.

Dalam kehidupan masyarakat senantiasa terjadi interaksi sosial antar pribadi, antar kelompok dan antar bangsa. Dalam prosesnya, individu senantiasa memperhatikan dan bereaksi terhadap individu atau kelompok lain sehingga ia akan merespon dengan suatu tingkah laku tertentu. Aspek-aspek yang terdapat dalam interaksi sosial adalah komunikasi, persepsi dan proses belajar. Dalam konteks ini selalu ada pengaruh dua arah yang saling mempengaruhi baik secara internal maupun eksternal. ${ }^{8}$

Namun dalam realitasnya, interaksi sosial tersebut tidak hanya dapat menciptakan kondisi kehidupan masyarakat yang kohesif dan harmonis, namun juga berpotensi menciptakan situasi konflik dimana umumnya disebabkan oleh faktor prasangka, baik prasangka sosial politik, prasangka rasial hingga prasangka agama. Konflik dalam perspektif kajian sosial dapat dipetakan menjadi dua jenis, yaitu perang saudara dan kerusuhan sosial dimana kedua jenis konflik ini sekarang banyak dijumpai dan jumlah korbannya cenderung lebih besar daripada korban perang antar negara. ${ }^{9}$

Tulisan ini akan mengelaborasi tentang strategi dakwah Jamaah Tablig dalam mengatasi konflik sosial di Kecamatan Masamba Kabupaten Luwu Utara.

\section{KAJIAN TEORETIK}

Kata strategi dalam konteks penelitian ini dikaitkan dengan dakwah, yakni suatu aktivitas penyampaian/syiar ajaran Islam kepada masyarakat (mad'u) baik yang dilakukan oleh individu (dai) maupun kelompok. Secara terminologi pengertian strategi adalah taktik atau cara yang disusun dengan seksama untuk mencapai suatu keberhasilan. Dalam strategi mengandung visi, misi, tujuan sasaran, kebijakan, program dan kegiatan yang nyata dengan mengantisipasi perkembangannya. Kurangnya penerapan dalam strategi yang baik dapat menyebabkan strategi yang direncanakan gagal. Akan tetapi, penetapan strategi dengan baik dapat mengokohkan strategi menjadi lebih efektif.

Kata "dakwah" sendiri berasal dari bahasa Arab, دَعَا - يَدْعُوْ - دَعْوَة yang berarti upaya untuk mengajak, menyeru, memanggil, seruan, permohonan, dan permintaan. ${ }^{1}$ Menurut Syekh Ali Mahfud, dakwah adalah sebagai upaya membangkitkan kesadaran

${ }^{8}$ Thoby Mutis dkk, Perdamaian dan Anti Kekerasan; Merajut Mozaik Budaya Bangsa (Jakaarta: Universitas Trisakti, 2005), h. 38.

${ }^{9}$ Dewi Fortuna Anwar, dkk, Konflik Kekerasan Internal; Tinjauan Sejarah, Ekonomi Politik dan Kebijakan di Asia Pasifik Edisi I (Jakarta:Yayasan Obor Indonesia, 2004), h. 117.

${ }^{1}$ Enjang AS dan Aliyuddin, ${ }^{0}$ Dasar-Dasar Ilmu Dakwah; Pendekatan Filosofis dan Praktis (Bandung: Widya Padjajaran, 2009), h. 3-14. 
manusia di atas kebaikan dan bimbingan, menyuruh berbuat ma'ruf dan mencegah perbuatan munkar supaya mereka mendapat kebahagiaan dunia dan akhirat. ${ }^{1}$

Dakwah, dapat juga diartikan sebagai upaya dai (orang yang menyampaikan pesan, seperti ulama, kiai ustadz atau mubalig) dalam menyampaikan pesan-pesan alQur'an dan Hadis kepada umat (khalayak) agar umat dapat mengetahui, memahami, menghayati dan mengamalkannya dalam kehidupan sehari-hari serta menjadikan alQur'an dan Hadis sebagai pedoman dan pandangan hidupnya. ${ }^{1}$

Dari pengertian-pengertian diatas, dapat dipahami bahwa dakwah adalah mengajak atau menyeru manusia ke jalan kebaikan dengan penuh kesadaran kemudian diamalkan dalam kehidupan sehari-hari sebagai pegangan hidup manusia baik di dunia maupun di akhirat. Setelah mengetahui pengertian dakwah, maka perlu adanya unsurunsur yang harus dipenuhi agar dapat berjalan dengan lancar dan tepat sasaran.

Aspek-aspek dakwah biasa juga dikenal dengan komponen atau unsur dakwah. Setiap aspek dakwah saling terkait antara satu dengan yang yang lainnya. Seorang dai yang terkenal apabila salah dalam penggunaan metode ketika berdakwah, maka dakwahnya tidak dijamin bisa berhasil. Sebaliknya metode yang baik juga tidak menjamin hasil yang baik, karena keberhasilan dakwah tersebut sangat ditunjang oleh seperangkat persyaratan yaitu pribadi dai, materi yang disampaikan, subjek dakwah ataupun aspek lainnya. ${ }^{1}$ 3

Pengetahuan dan pemahaman tentang aspek dakwah sangatlah penting, mengingat bahwa manusia sebagai objek dakwah adalah individu yang memiliki karakteristik tersendiri dan berbeda antara satu dengan yang lainnya. Perbedaan karakter serta ragam perbedaan yang lainnya pada diri objek dakwah inilah yang mengharuskan adanya perencanaan atau strategi yang tepat dalam berdakwah.

Upaya peningkatan kualitas aktivitas dakwah sangat berkaitan dengan usaha meningkatkan kualitas seluruh aspek atau komponen dakwah yakni; 1) subyek dakwah (dai), 2) obyek dakwah (madú), 3) materi dakwah, 4) sarana atau media dakwah, 5) metode dakwah, dan 6) tujuan dakwah. ${ }^{1}$ Dengan peningkatan kuafitas seluruh aspek atau komponen dakwah tersebut, maka dakwah yang dilakukan diharapkan dapat mencapai hasil yang lebih maksimal.

Konflik sosial, adalah suatu pertentanngan yang terjadi antara dua pihak dan masing-masing berusaha mempertahankan hidup, eksistensi, dan prisipnya. Secara sosiologis, konflik diartikan sebagai suatu proses sosial antara dua orang atau lebih (bisa juga kelompok) di mana salah satu pihak berusaha menyingkirkan pihak lain dengan menghancurkannya atau membuatnya tidak berdaya. Hassan Shadily, mengartikan konflik sosial sebagai proses yang menunjukkan pengaruh menentang antara perseorangan atau golongan dalam mengejar tujuan yang sama. ${ }^{1}$

${ }^{1}$ RB. Khatib Pahlawan Kayyo, Manajemen Dakwah; Dari Dakwah Konvensional Menuju Dakwah Profesional (Jakarta: Amzah, 2007), h. 25-26.

${ }^{1}$ Wahyu Ilaihi, Komunikasi Dakwah (Bandung: Remaja Rosdakarya, 2013) h. 26.

${ }^{1}$ M. Quraish Shihab, Membủmikan Al-Qurán: Fungsi dan Peran Wahyu dalam Kehidupan Masyarakat, h. 194.

${ }^{1}$ Asep Muhyiddin dan Agus Ahmad Safei, Metode Pengembangan Dakwah (Cet. I, Bandung: Pustaka Setia, 2002), h. 133.

${ }^{1}$ Hassan Shadily, Sosiologi uñtuk Masyarakat Indonesia (Cet.XI, Jakarta: Bina Aksara, 1989), h.103. 
Perspektif sosiologi, memandang masyarakat sebagai satu sistem yang terdiri dari bagian atau komponen yang mempunyai kepentingan yang berbeda-beda dimana komponen yang satu berusaha menaklukkan kepentingan yang lain guna memenuhi kepentingannya atau memperoleh keuntungan yang sebesar-besarnya. Dalam pandangan ahli sosiologi, masyarakat yang baik ialah masyarakat yang hidup dalam situasi konfliktual. Konflik sosial dianggap sebagai kekuatan sosial utama dari perkembangan masyarakat yang ingin maju ketahap-tahap yang lebih sempurna. Teori konflik sosial memandang antar elemen sosial memiliki kepentingan dan pandangan yang berbeda. Perbedaan kepentingan dan pandangan tersebut yang memicu terjadinya konflik sosial yang berujung saling mengalahkan, melenyapkan, memusnahkan diantara elemen lainnya. ${ }^{1}$

Konflik dilatarbelakangi oleh perbedaan ciri-ciri yang dibawa individu dalam suatu interaksi. Perbedaan-perbedaan tersebut diantaranya menyangkut ciri fisik, kepandaian, pengetahuan, adat istiadat, keyakinan dan lain sebagainya. Dengan adanya ciri-ciri individual dalam interaksi sosial, maka konflik merupakan situasi yang wajar terjadi dalam setiap bermasyarakat dan tidak ada satu pun masyarakat yang tidak pernah mengalami konflik antara anggotanya atau dengan kelompok masyarakat yang lain, konflik ini hanya akan hilang bersamaan dengan hilangnya sebuah masyarakat itu sendiri.

Bertolak dari asumsi di atas, maka sesungguhnya adanya sejumlah perbedaan dalam kehidupan sosial merupakan suatu hal yang wajar dan tidak perlu menjadi penyebab timbulnya konflik. Sebab dalam menata kehidupan bermasyarakat diperlukan sejumlah teori dan cara yang boleh jadi di antara teori dan cara-cara itu saling berbeda. Tetapi justru perbedaan itu memperkaya dinamika kehidupan masyarakat.

Jamaah Tablig atau "Kelompok Penyampai" (جماعة التبليغ juga disebut Tabliq), adalah gerakan transnasional dakwah Islam yang didirikan oleh Muhammad Ilyas pada tahun 1926 di India. ${ }^{1}$ Nama lengkapnya adalah Muhammad Ilyas bin Muhammad Isma'il al-Hanafi ad-Diyubandi al-Jisyti al-Kandahlawi kemudian ad-Dihlawi. AlKandahlawi merupakan asal kata dari Kandahlah, sebuah desa yang terletak di daerah Sahranfur. Sementara ad-Dihlawi adalah nama lain dari Dihli (New Delhi), ibu kota India. Di negara inilah markas gerakan Jamaah Tablig berada. Adapun ad-Diyubandi adalah asal kata dari Diyuband, yaitu madrasah terbesar bagi penganut Madzhab Hanafi di semenanjung India. Sedangkan Al-Jisyti dinisbatkan kepada tarekat al-Jisytiyah, yang didirikan oleh Mu'inuddin al-Jisyti. ${ }^{1}$

Nama Jamaah Tablig hanyalah merupakan sebutan bagi mereka yang sering menyampaikan, sebenarnya usaha ini tidak mempunyai nama tetapi cukup Islam saja tidak ada yang lain. Bahkan Muhammad Ilyas mengatakan seandainya aku harus memberikan nama pada usaha ini maka akan aku beri nama "gerakan iman". Ilham untuk mengabdikan hidupnya total hanya untuk Islam terjadi ketika Maulana Ilyas melangsungkan Ibadah Haji keduanya di Hijaz pada tahun1926.

${ }^{1}$ Dany Haryanto dan G. Edwi Nugroho, Pengantar Sosiologi Dasar, h. 92.

${ }^{1}$ Jamaah Tablig, Wikipedia Bahasa Indonesia; Ensiklopedia Bebas. https://id.wikipedia.org/w/index.php?title=Jamaah_Tabligh\&oldid=11451783 (diakses pada 21 Juni 2016).

${ }^{1}$ Ahmad Syafi'i Mufid, Perke̊mbangan Paham Keagamaan Transnasional di Indonesia Edisi I (Cet. I, Jakarta: Badan Litbang dan Diklat Kementerian Agama RI, 2011), h. 147. 
Jamaah Tablig muncul sebagai gerakan yang mengimbangi gerakan pengalihan Hindu yang agresif di India pada saat itu. Maulana Ilyas berkeyakinan bahwa gerakan keagamaan Islam yang kultural merupakan metode yang dapat memurnikan kaum muslim dari kehidupan mereka. Institusi pendidikan tradisional yang disebut dengan "madrasah" pun didirikan sebagai langkah awal memperbaiki dan mendidik kaum muslim. Wilayah Mewat sebagai tempat kelahiran Jamaah Tablig berhasil membentuk jaringan sekolah-sekolah agama berbasis masjid yang mengajarkan praktek keislaman yang benar. ${ }^{1}$

Maulana Ilyas menyeru manusia kepada Islam dengan menggunakan cara yang sederhana. Caranya adalah mengorganisasi unit-unit yang terdiri at as sekurag-kurangnya sepuluh orang dan mengirim mereka ke pelbagai kampung. Unit-unit tablig ini, dikenal sebagai jamaah (kelompok) yang akan mengunjungi sebuah kampung, mengundang kaum muslimin setempat untuk berkumpul di masjid atau satu tempat berkumpul lainnya, lalu menyampaikan pesan mereka dalam bentuk mengikuti enam tuntunan. Konsep gerakan dakwah yang digagas oleh Maulana Ilyas ini mengambil jalur diluar wilayah politik. Menurut Maulana Ilyas, jamaah tidak akan mampu mencapai tujuannya jika mengambil bagian di wilayah politik praktis. ${ }^{2}$ 0

Sepeninggal Syekh Maulana Ilyas, tampuk kepimimpinan Jamaah Tablig diteruskan oleh putranya, Syekh Muhammad Yusuf al-Kandahlawi. Ia lahir pada 25 Jumadil Awal 1335 H / 20 Maret 1917 di Desa Kandahlah, India. Muhammad Yusuf sudah hafal al-Qur'an pada usia sepuluh tahun. Selepas tamat belajar al-Qur'an, ia melanjutkan dengan mempelajari Hadis dan ilmu-ilmu Islam lainnya. Dia juga menghabiskan sebagian besar masa dewasanya dengan melakukan perjalanan bersama kelompok-kelompok pengkhutbah di seluruh Anak Benua India-Pakistan. Selama di bawah kepemimpinannya, gerakan operasi Jamaah Tablig diperluas hingga melintasi provinsi-provinsi di bagian utara India. Ia juga menggalang ribuan kelompok untuk melakukan perjalanan ke seluruh India. Selama masa jabatannya pula, aktivitas Jamaah Tablig menyebar ke negeri-negeri di Asia Tenggara, Timur Tengah, Afrika, Eropa, dan Amerika Utara. Ia wafat di Lahore dalam usia 48 tahun. $^{2}$

Jamaah Tablig dalam menjalankan aktifitasnya, memegang konsep dakwah yang dikenal dengan istilah ushul al-sittah (enam landasan pokok) atau al-sifat al-sittah (sifat yang enam) dalam setiap dakwahnya. Enam landasan pokok ini adalah merupakan rangkuman dari sifat-sifat para Sahabat Nabi saw. yang kemudian disebut dengan Enam Sifat Sahabat.

Enam Sifat Sahabat tersebut kemudian ditopang dengan atauran (tertib dakwah) yang dikenal dengan usul-usul dakwah yang berjumlah dua puluh delapan usul. Usul dakwah tersebut merupakan rambu-rambu bagi siapa saja yang ikut dalam usaha dakwah Jamaah Tablig khususnya pada saat khuruj fii sabilillah (keluar di jalan Allah).

\section{METODOLOGI PENELITIAN}

Penelitian ini adalah penelitian lapangan (fild reseach) yang digolongkan sebagai penelitian deskriptif kualitatif. Penelitian ini yang dilaksanakan di Kecamatan Masamba Kabupaten Luwu Utara. Pendekatan yang digunakan dalam penelitian ini

${ }^{1}$ John L. Esposito, Ensiklopedia Dunia Islam Modern (Cet. II; Bandung: Mizan, 2002), h. 35-36.

2 John L. Esposito, Ensiklopedia Dunia Islam Modern, h. 39.

2 John L. Esposito, Ensiklopedia Dunia Islam Modern, h. 30. 
adalah pendekatan sosiologis, pendekatan komunikasi, dan pendekatan historis, serta teori-teori yang relevan dengan kajian konflik sosial dan gerakan dakwah Jamaah Tablig. Jenis data yang digunakan dalam penelitian ini yaitu data primer dan sekunder. Data primer diperoleh dari informan baik itu melalui wawancara atau peneliti sendiri yang melakukan observasi. Sedangkan data sekunder merupakan data yang tidak langsung diambil dari para informan akan tetapi memalui dokumen. Metode pengumpulan data kualitatif dapat dilakukan dengan observasi (pengamatan), interview (wawancara), dokumentasi. Dalam upaya memperoleh data yang empiris mengenai masalah yang diamati dalam penelitian ini digunakan seperangkat instrumen dalam bentuk pedoman wawancara (interview guide), alat rekam peristiwa seperti tape recorder dan kamera, serta catatan lapangan (field note) untuk menghimpun informasi mengenai strategi dakwah Jamaah Tablig dalam mengatasi konflik sosial di Kecamatan Masamba Kabupaten Luwu Utara. Data diolah dan dianalisis dengan reduksi data, penyajian data, dan penarikan kesimpulan dengn uji keabsahan data melalui triangulasi.

\section{HASIL PENELITIAN DAN PEMBAHASAN}

Berdasarkan penelusuran data lapangan, diketahui bahwa kehadiran Jamaah Tablig di Masamba sudah ada sejak lama. Menurut keterangan seorang tokoh masyarakat sebagai anggota aktif Jamaah Tablig dan termasuk salah satu orang pertama yang mengikuti kegiatan Tablig di Masamba, mengungkapkan bahwa gerakan dakwah Jamaah Tablig sudah berlangsung di Masamba sejak awal tahun 1990-an, namun jumlahnya masih sedikit. Gerakan dakwah Jamaah Tablig terasa pangaruhnya pada tahun 1998, bertepatan dengan situasi masyarakat Masamba yang saat itu sedang dilanda konflik. Berikut penuturan informan mengenai kehadiran Jamaah Tablig yang diut us dari luar daerah untuk melaksanakan dakwah di Masamba:

Jamaah pertama kali bergerak ke Masamba itu sekitar tahun 1998. Pada saat itu jamaah terbagi menjadi dua rombongan, rombongan pertama yang di kirim adalah jamaah 4 bulan jalan kaki yang berjumlah kalau tidak salah sekitar 13 orang. Rombongan kedua adalah jamaah 40 hari biasa yang jumlahnya 11 orang dengan saya. Waktu kami dikirim kesana rupanya disana sementara kacau. Saat kami tiba disana, rombongan pertama yaitu jamaah 4 bulan jalan kaki yang sudah tiba disana dua minggu sebelumnya rupanya ada di kantor polisi sementara diperiksa dan ditahan untuk sementara waktu karena dicurgai sebagai pelaku teroris. ${ }^{2}$

Data yang diungkapkan informan tersebut di atas, menyebutkan suatu masa dimana pergerakan dakwah Jamaah Tablig diperhadapkan dengan realitas kondisi masyarakat Indonesia yang mengalami krisis multidimensi dan masa transisi politik pemerintahan, dari rezim orde baru menuju reformasi pada tahun 1998-1999. Dinamika sosial politik tersebut tentunya disadari oleh kalangan Jamaah Tablig sebagai tantangan dakwah tersendiri, terutama gejala konflik sosial yang hampir melanda seluruh daerah di Indonesia. Faktanya, sebagaimana penuturan informan sebelumnya, menyatakan bahwa Jamaah Tablig telah mengutus kelompok atau rombongan ke daerah Masamba yang rawan konflik meskipun tujuan utama mereka sesungguhnya bukan mengatasi konflik sosial tersebut.

Temuan data lapangan menunjukkan bahwa tujuan utama Jamaah Tablig di Masamba semata hanya melakukan kegiatan dakwah kepada masyarakat, meski

\footnotetext{
${ }^{2}$ Agung (48), Penggiat Jamaah Tablig Makassar. Wawancara, Masamba, 09 Maret 2017
} 
demikian pihak Jamaah Tablig sendiri mengakui bahwa kategori masyarakat (mad'u) yang menjadi prioritas sasaran dakwahnya adalah kalangan yang "bermasalah" atau umat yang sudah menyimpang dari ajaran Islam. Pada kenyataannya, Jamaah Tablig cenderung kurang menyent uh kalangan akademisi, intelektual, dan warga yang dianggap telah memahami dan melaksanakan syariat Islam, melainkan Jamaah Tablig secara umum dan khususnya di Masamba lebih memprioritaskan kelompok pemuda untuk direkrut sebagai anggota karena kalangan ini dianggap lebih dominan berperilaku menyimpang dari syariat Islam. Hal ini sejalan dengan realitas konflik sosial di Masamba, di mana kelompok pemuda memang ditengarai banyak pihak menjadi akar penyebab konflik yang meluas hingga melibatkan pertikaian antar warga desa di Masamba.

Dengan demikian, kehadiran Jamaah Tablig di Masamba sesungguhnya menemukan momentumnya, dimana sasaran dakwah Jamaah Tablig jelas menyasar kelompok-kelompok pemuda yang sering berkonflik. Ditinjau dari aspek keanggotaan, fakta menunjukkan mayoritas anggota yang berhasil direkrut oleh Jamaah Tablig pasca konflik sosial di Masamba, adalah kalangan pemuda yang notabene sebagai pelaku utama dari konflik tersebut. Dari sisi inilah dapat dijelaskan bahwa Jamaah Tablig melakukan transformasi sosial dengan menerapkan strategi dakwah tersendiri dalam menghadapi realitas kondisi sasaran dakwahnya (mad'u) untuk selanjutnya direkrut sebagai anggota Jamaah Tablig.

Berdasarkan reduksi dan kategorisasi temuan data lapangan, berikut diuraikan penyajian data empiris mengenai langkah-langkah strategi dakwah Jamaah Tablig dalam realitas konflik sosial di Masamba. Pembahasan ini dibagi menjadi empat sub kategori pembahasan antara lain, proses identifikasi Jamaah Tablig terhadap kondisi masyarakat Masamba, proses sosialisasi pesan keagamaan oleh Jamaah Tablig melalui metode konvensional, rekrutmen keanggotaan dan indoktrinasi paham keagamaan, dan membangun relasi dengan pemerintah dan tokoh masyarakat.

a. Identifikasi Kondisi Masyarakat dan Pemetaan Sasaran Dakwah

Kehadiran Jamaah Tablig di Masamba merupakan kegiatan rutin dan bertujuan sama dengan Jamaah Tablig di berbagai daerah lainnya, yakni mengemban misi dakwah dengan metode konvensional. Namun mengingat kehadiran Jamaah Tablig di Masamba di masa konflik yang tengah bergejolak dan mereka juga bersentuhan langsung dengan masyarakat Masamba, maka Jamaah Tablig menyusun strategi dengan menyesuaikan realitas sosial tersebut. Dalam konteks ini, misalnya Jamaah Tablig mencermaati realitas konflik yang terjadi di Masamba pada tahun 1998, yang cenderung diisukan bernuansa konflik keagamaan, antara umat Islam dengan Kristen. Isu yang berkembang tersebut kemudian menjadi dasar pertimbangan bagi Jamaah Tablig untuk memetakan sasaran dakwahnya di Masamba.

Hasil wawancara dengan informan dari Jamaah Tablig menuturkan bahwa sebelum kelompok-kelompok Jamaah Tablig diutus ke daerah Masamba, elemen pimpinan (Amir) Jamaah Tablig memang telah mengidentifikasi sejak awal kondisi masyarakat setempat, khususnya memetakan sasaran dakwah ( ad' ) yang berpotensi direkrut sebagai anggota Jamaah Tablig. Berikut diuraikan penuturan informan terkait hasil identifikasi Jamaah Tablig tentang kondisi masyarakat Masamba yang tengah berkonflik dengan sasaran utama rekrutmen anggota Jamaah Tablig adalah kelompok pemuda yang dikategorikan sebagai pelaku utama konflik sosial di Masamba: 
Sebelum ke Masamaba, kami gali informasi itu dari tokoh masyarakat, isu yang berkembang saat itu pertikaian yang melibatkan warga pendatang dari Tana Toraja yang tinggal di Kelurahan Kasimbong dengan penduduk asli Masamba di Desa Laba yang mempersoalkan masalah lahan perkebunan. Tokoh masyarakat yang kami temui saat itu mengatakan banyak rumah yang terbakar akibat warga bertikai dan menelan beberapa korban nyawa. Informasi ini kami jadikan pertimbangan supaya bisa dilakukan pendekatan kepada kelompok-kelompok pemuda yang menjadi pelaku utama dari pertikaaian itu. ${ }^{2}$

Berdasarkan penuturan informan di atas, diketahui bahwa sasaran dakwah yang diprioritaskan atau menjadi target utama untuk direkrut oleh Jamaah Tablig adalah kelompok pemuda yang dikategorkan sebagai pelaku konflik dimana sebagian di antaranya adalah para pimpinan atau orang yang cukup disegani dalam kelompok pemuda tersebut. Seperti yang telah disinggung sebelumnya, cukup beralasan bagi Jamaah Tablig menyasar kelompok pemuda sebagai sasaran dakwah (mad'u) terutama para pimpinan kelompok pemuda tersebut, sebab kapasitas pimpinan kelompok pemuda dianggap memiliki pengaruh kepada anggotanya. Ketika pimpinan kelompok pamuda sudah aktif sebagai karkun (rekan usaha dalam dakwah dan tablig), selanjutnya mereka memengaruhi atau mengajak teman-teman atau anggotanya yang lain untuk ikut bergabung bersama-sama dengannya dalam usaha dakwah.

b. Sosialisasi Pesan Dakwah dengan Metode Konvensional

Strategi dakwah selanjutnya yang dilakukan oleh Jamaah Tablig di Masamba adalah melakukan sosialisasi atau kunjungan langsung ke warga secara informal dan persuasif. Pendakatan secara informal dan persuasif terhadap individu-individu warga Masamba dilakukan Jamaah Tablig juga terkait dengan pertimbangan hasil identifikasi kondisi masyarakat yang tengah berkonflik. Strategi dakwah demikian tampaknya sama dengan pendekatan dakwah bil hikmah. Dalam konteks ini, cara perekrutan Jamaah Tablig kepada pelaku konflik khususnya yang beragama Islam dilakukan secara perlahan dengan mendatangi satu-persatu dari rumah ke rumah orang-orang yang terlibat konflik utamanya warga yang sangat berpengaruh dalam kelompoknya. Dengan demikian strategi dakwah Jamaah Tablig meralisasikan metode dakwah bil hikmah, dimana metode dakwah yang mereka gunakan dengan cara yang santun dan penuh hikmah, menyampaikan kebesaran Allah swt dan keuntungan bagi orang-orang yang selalu menjaga hubungan silaturahmi dengan tetangga rumah maupun tetangga kampungnya.

Seorang mantan pelaku konflik mengungkapkan bahwa gerakan dakwah yang dilakukan oleh Jamaah Tablig sangat proaktif kepada mereka saat itu, hampir setiap hari mereka mendatangi orang-orang yang sering terlibat konflik. Kemudian mengajak mereka ke masjid untuk melaksanakan shalat dan mengikuti program-program yang telah mereka buat, diantaranya mendengarkan bayan atau ceramah agama, mendengarkan taklim, melaksanakan shalat malam serta aktifitas-aktifitas lainnya yang menjadi rutinitas Jamah Tablig saat melaksanakan program maqami (kerja dakwah yang dilakukan di lingkungan sendiri).

c. Rekrutmen Keanggotaan dan Pelaksanaan Program Dakwah

Tahapan sosialisasi atau pendekatan langsung kepada warga Masamba yang telah dipaparkan sebelumnya, bertujuan merekrut warga untuk menjadi anggota Jamaah Tablig. Jamaah Tablig kemudian menindaklanjuti proses itu dengan cara mengukuhkan

\footnotetext{
${ }^{2}$ Agung (48), Penggiat Jamaah̉ Tablig Makassar. Wawancara, Masamba, 09 Maret 2017
} 
mereka sebagai anggota yang siap melaksanakan program-program dakwah Jamaah Tablig. Temuan data lapangan menunjukkan fakta bahwa Jamaah Tablig berhasil merekrut anggota yang relatif banyak di Masamba, khususnya saat peristiwa konflik sosial berlangsung di Masamba. Gerakan dakwah Jamaah Tablig mulai berkembang sampai ke pelosok-pelosok desa yang ada di wilayah Masamba, terbukti saat kegiatan Jord'pertama yang dilakukan pada tahun 2002 yang mengumpulkan anggota jamaahnya sekitar 4 ribu orang, dan mengeluarkan jamaahnya untuk keluar berdakwah sebanyak 2 rombongan jamaah 4 bulan jalan kaki dan 4 rombongan 40 hari biasa. ${ }^{2}$

Langkah selanjutnya yang dilakukan oleh para penggiat dakwah Jamaah Tablig terhadap anggota yang baru bergabung yaitu ikut keluar tiga hari di jalan Allah bersama mereka untuk memperbaiki diri. Anggota yang baru bergabung dan sudah mengikuti program selama tiga hari, selanjutnya diikutkan dalam program khuruj (keluar di jalan Allah) selama 40 hari keluar kampung. Selama melakukan khurujj, para anggota yang mengikuti kegiatan sebisa mungkin harus meninggalkan urusan-urusan dunia, misalnya pekerjaan, pendidikan, ekonomi, politik dan lain-lain yang bisa mengganggu kehusyuan dalam ibadah. Kegiatan selama khuruj berlangsung terbagi menjadi dua, yaitu kegiatan infirodi (yang dilakukan secara pribadi) dan kegiatan ijtimaí (yang dilakukang secara bersama-sama).

Amalan ijtimaí adalah merupakan suatu hal yang lebih diutamakan dibanding amalan infirodi, sebab ciri utama dari jamaah ini adalah sering melakukan amalan atau kegiatan secara berjamaah atau bersama-sama. Amalan ijtimaí adalah shalat lima waktu, mendengarkan bayan atau ceramah, mendengarkan ta'lim (pembacaan kitab fadilah amal) dan makan yang selalu dilakukan secara berjamaah. Sedangkan amalan infirodi yaitu membaca al-Qurán, shalat-shalat sunnah, dzikir dan ibadah lain yang bias meningkatkan keimanan dan sikap istiqamah dalam menjalankan ajaran Islam.

d. Membangun Relasi dengan Pemerintah dan Tokoh Masyarakat

Temuan data lapangan menunjukkan kenyataan terjadinya hubungan simbiosis mutualis antara tokoh masyarakat dan pemerintah dengan Jamaah Tablig dalam rangka mengatasi konflik sosial di Masamba. Dalam hal ini, terjadi pertemuan antara tokoh masyarakat dan elemen pemerintah dengan unsur pimpinan Jamaah Tablig, guna mendialogkan tentang strategi pemecahan dari konflik di Masamba. Kesimpulan yang dicapai dari pertemuan tersebut, menunjukan sebuah resolusi konflik dengan mengedepankan peran Jamaah Tablig untuk memberdayakan kelompok-kelompok pemuda dan termasuk sebagian warga yang berstatus pelaku konflik, melalui program khuruj berbasis pesantren.

Program khuruj tentunya merupakan program dakwah yang rutin dilakasanakan oleh anggota Jamaah Tablig dengan bermodal pengorbanan (harta dan fisik) dan kesukarelaan para anggotanya. Namun untuk pertama kalinya dan mungkin baru terjadi dalam sejarah pergerkan dakwah Jamaah Tablig, gerakan mereka diakomodasi oleh pemerintah. Realitasnya, anggota-anggota kelompok pemuda di Masamba yang berhasil direkrut oleh Jamaah Tablig dan kemudian mereka dikirim untuk mengikuti program khuruj berbasis pesantren di Pondok Pesantren Temboro Magetan Jawa Timur, yang dibiayai oleh pemerintah.

\footnotetext{
2 Jord' ialah satu perhimpunant tahunan yang diadakan untuk membentuk rombongan sebanyakbanyaknya untuk keluar bersama-sama untuk berdakwah. Baca Mudzakarah Khuruj Fī Sabilillah (Bandung: Pustaka Ramadhan, 2010)
} 
Dengan demikian sebenarnya pemerintah Masamba mengintervensi secara tidak langsung gerakan dakwah Jamaah Tablig, meskipun sebatas menyodorkan biaya aktivitas dakwah. Secara internal dipahami bahwa pembiayaan segala aktivitas dakwah Jamaah Tablig bersumber dari sumbangan atau swadaya para anggotanya atas rasa suka rela sebagai bentuk realisasi prinsip Jamaah Tablig yakni pengorbanan harta. Kenyataan ini menunjukkan sebuah inkonsistensi atau semacam pergeseran makna prinsipil yang dijunjung tinggi oleh Jamaah Tablig, bahwa mereka menolak untuk terlibat dalam politik dan urusan-urusan ekonomi yang dapat memengaruhi usaha dakwah yang dilaksanakan. Namun pada akhirnya Jamaah Tablig membuka ruang bagi pemerintah Masamba untuk membantu usaha dakwah, dengan alasan untuk kemaslahatan umat karena kedua pihak (pemerintah dan Jamaah Tablig) diperhadapkan pada masalah yang sama, yakni konflik sosial di Masamba.

Terlepas dari pandangan masyarakat yang selama ini menganggap Jamaah Tablig cenderung tertutup atau tidak melibatkan pihak lain dalam melaksanakan usaha dakwahnya, sisi positif dari kerjasama pemerintah dengan Jamaah Tablig setidaknya mampu meredam konflik sosial yang sempat meluas di Masamba khususnya periode konflik 1998 hingga 2002. Program Khuruj berbasis pesantren semestinya tetap dilaksanakan oleh Jamaah Tablig dengan atau tanpa bantuan pemerintah sekalipun, mengingat konflik sosial di Masamba berpotensi terulang dengan pelaku yang sama seperti yang baru terjadi pada tahun 2013-2015.

Adapun capaian Jamaah Tablig atas pelaksanaan dakwah di Masamba, tidak menunjukkan perubahan yang signifikan pada masyarakat. Meskipun ada perubahan, namun hal itu bersifat temporal dan hanya terjadi pada sebagian kecil anggota Jamaah Tablig yang berhasil direkrut sebelumnya secara besar-besaran. Hal ini misalnya dilihat dari banyaknya orang-orang yang terlibat konflik tiba-tiba berubah menjadi orang yang taat dalam beribadah dan aktif di masjid, seperti yang diungkapkan oleh salah seorang tokoh agama Desa Laba, mengatakan bahwa:

Alhamdulillah selama ada Jamaah Tablig di sini, sudah jarang didengar ada perangperang antara kampung, kurangmi juga kita lihat anak-anak muda yang minumminum ballo, aktifmi di masjid dan sering keluar pergi berdakwah. Kadang amasih ada juga yang minum ballo dan berkelahi, tapi sudah nda separah dulu. ${ }^{2}$

Namun seiring berjalannya waktu, keterangan yang diungkapkan informan tersebut menunjukkan kondisi yang berbeda, dimana perubahan pada warga Masamba yang bergabung menjadi anggota Jamaah Tablig tidak bertahan lama atau keanggotaan Jamaah Tablig kini semakin berkurang. Faktanya, menurut pengakuan anggota Jamaah Tablig yang masih aktif sampai sekarang, mengatakan bahwa sebagian dari pelaku konflik terbaru di Masamba (tahun 2013-2015) adalah anggota yang pernah bergabung sebagai Jamaah Tablig tetapi mereka kembali ke jalan mengikuti tabiat kelompoknya. Berdasarkan uraian sebelumnya, temuan data lapangan hanya menunjukkan beberapa indikator keberhasilan dakwah Jamaah Tablig terhadap warga yang berkonflik di Masamba, sebagai berikut:

1) Dakwah Jamaah Tablig berhasil meredam eskalasi konflik dengan cara merekrut pimpinan dan anggota-anggota kelompok yang sering berkonflik

2) Proses pembinaan Jamaah Tablig terhadap warga dilakukan melalui Khuruj 40 hari 4 Bulan berdakwah ke luar daerah Masamba

\footnotetext{
${ }^{2}$ Syarifuddin (50 tahun) Tokoh Agama Masamba, Wawancara, Masamba, 12 Maret 2017
} 
3) Sinergi pemerintah dengan Jamaah Tablig menghasilkan resolusi konflik yakni khuruj berbasis pesantren atau pelaku konflik di pesantrenkan.

Selanjutnya dari hasil identifikasi data lapangan menunjukkan beberapa indikator penyebab konflik sosial di Masamba kembali terulang pada tahun 2013-2015 dan sejauhmana gerakan dakwah Jamaah Tablig dalam situasi konflik sosial di Masamba, antara lain dijelaskan sebagai berikut:

1) Subkultur menyimpang pada kelompok-kelompok pemuda masih menjadi tradisi atau membudaya hingga saat ini

2) Konflik 1998-2002 tidak terselesaikan dengan baik sehingga pelaku-pelaku lama kembali mengungkit dendamnya

3) Indikasi konflik sosial sengaja didorong agar kembali terjadi oleh pihak-pihak yang berkepentingan dalam momentum Pemilukada

4) Dakwah Jamaah Tablig kurang efektif dari segi mempertahankan anggotanya, sebab warga pelaku konflk yang berhasil direkrut dan disadarkan sebagian kembali ke aktifitas sebelumnya.

Tantangan dakwah yang utama dihadapi oleh Jamaah Tablig adalah bagaimana mengubah subkultur menyimpang pada kelompok-kelompok pemuda yang masih membudaya hingga saat ini. Subkultur meyimpang pada kelompok pemuda ini tent unya menjadi salah satu faktor penyebab terjadinya konflik sosial di Masamba, dimana budaya dikalangan pemuda cenderung menunjukkan perilaku kekerasan, tradisi mengkonsumsi minuman keras dan berbagai aktivitas yang menyimpang dari norma sosial dan agama.

Berdasarkan rangkaian hasil penelitian dan pembahasan di atas, dapat disimpulkan bahwa strategi dakwah Jamaah Tablig di Masamba cukup efektif dari segi perekrutan, namun kurang efektif dalam hal mempertahankan anggota. Kurang efektifnya peran Jamaah Tablig karena perubahan pada sasaran dakwah tidak bertahan lama atau bersifat sesaat/temporal. Warga pelaku konflik yang berhasil direkrut dan disadarkan melalui program dakwah Jamaah Tablig, sebagian kembali ke aktifitas mereka yang menyimpang. Di satu sisi Jamaah Tablig sukses dalam hal perekrutan, namun kurang efektif dalam hal mempertahankan anggotanya agar tetap aktif dalam aktifitas usaha dakwahnya.

\section{PENUTUP}

Berdasarkan paparan di atas, maka dapat disimpulkan bahwa strategi dakwah yang dilakukan oleh Jamaah Tablig dalam mengatasi konflik sosial di Kecamatan Masamba adalah dengan cara; a) Jaulah, yakni silaturahmi mengunjungi para pelaku konflik untuk mengingatkan agar sama-sama taat kepada Allah; b) Bayan, yakni memberikan penerangan atau ceramah agama; c) Tasykil, yakni mengajak para pelaku konflik dengan memberikan semangat untuk meluangkan waktu di jalan Allah; dan d) Bersinergi dengan pemerintah yang menghasilkan resolusi konflik yakni khuruj berbasis pesantren atau pelaku konflik di pesantrenkan. 


\section{DAFTAR PUSTAKA}

Anwar, Dewi Fortuna, dkk, Konflik Kekerasan Internal; Tinjauan Sejarah, Ekonomi Politik dan Kebijakan di Asia Pasifik Edisi I Jakarta:Yayasan Obor Indonesia, 2004.

Arifin, Anwar, Dakwah Kontemporer; Sebuah Studi Komunikasi, Cet. I; Yogyakarta: Graha Ilmu, 2011.

Arnold, Thomas Walker, The Preaching of Islam; A History of the Propagation of the Muslim Faith, terj. A. Nawawi Rambe, Sejarah Dakwah Islam Jakarta: Wijaya, 1985.

Aziz, Moh. Ali, Ilmu Dakwah, Edisi Revisi.

Enjang AS dan Aliyuddin, Dasar-Dasar Ilmu Dakwah; Pendekatan Filosofis dan Praktis Bandung: Widya Padjajaran, 2009.

Esposito, John L., Ensiklopedia Dunia Islam Modern Cet. II; Bandung: Mizan, 2002.

Faizah dan Lulu Muchsin Efendi, Psikologi Dakwah Cet. II; Jakarta: Kencana, 2009.

Hafidhuddin, Didin, Dakwah Aktual, Cet. I; Jakarta: Gema Insani Prees, 1998.

Idris, La Malik, Strategi Dakwah Kontemporer Cet. I; Makassar: Sarwah Press, 2007.

Ilaihi, Wahyu, Komunikasi Dakwah, Bandung: Remaja Rosdakarya, 2013.

Jamaah Tablig, Wikipedia Bahasa Indonesia; Ensiklopedia Bebas. https://id.wikipedia.org/w/index.php?title=Jamaah_Tabligh\&oldid=11451783 diakses pada 21 Juni 2016.

Kayyo, RB. Khatib Pahlawan, Manajemen Dakwah; Dari Dakwah Konvensional Menuju Dakwah Profesional Jakarta: Amzah, 2007.

Mudzakarah Khuruj Fi Sabilillah (Bandung: Pustaka Ramadhan, 2010.

Mufid, Ahmad Syafi'i, Perkembangan Paham Keagamaan Transnasional di Indonesia Edisi I Cet. I, Jakarta: Badan Litbang dan Diklat Kementerian Agama RI, 2011.

Muhyiddin, Asep dan Agus Ahmad Safei, Metode Pengembangan Dakwah Cet. I, Bandung: Pustaka Setia, 2002.

Mutis, Thoby dkk, Perdamaian dan Anti Kekerasan; Merajut Mozaik Budaya Bangsa Jakaarta: Universitas Trisakti, 2005.

Shadily, Hassan, Sosiologi untuk Masyarakat Indonesia, Cet.XI, Jakarta: Bina Aksara, 1989.

Shihab, M. Quraish, Membumikan al-Qurán Cet. XXII; Bandung: Mizan, 2001.

Agung (48), Penggiat Jamaah Tablig Makassar. Wawancara, Masamba, 09 Maret 2017

Syarifuddin (50 tahun) Tokoh Agama Masamba, Wawancara, Masamba, 12 Maret 2017. 